Selection of Islands for Conservation in the Urban Archipelago of Helsinki, Finland

Ranta, P.

Blackwell Publishing

1999

Ranta, P. et al. 1999. Selection of Islands for Conservation in the Urban Archipelago of Helsinki, Finland. Conservation Biology 13: 1293-1300.

http://hdl.handle.net/1975/257

Downloaded from Helda, University of Helsinki institutional repository.

This is an electronic reprint of the original article.

This reprint may differ from the original in pagination and typographic detail.

Please cite the original version. 


\title{
Selection of Islands for Conservation in the Urban Archipelago of Helsinki, Finland
}

\author{
PERTTI RANTA, ${ }^{\circledR}$ ¿ANTTI TANSKANEN, † JARI NIEMEL $\ddot{A},{ }^{*}$ AND ARTO KURTTO $\ddagger$ \\ *Department of Ecology and Systematics, P.O. Box 17, University of IIelsinki, FIN-00014, Helsinki, Finland \\ † Metsätähti I.td. Hitsaajankatu 1, FIN-00810, Helsinki, Finland \\ $\ddagger$ Botanical Museum, Finnish Museum of Natural History, P.O. Box 7, University of Helsinki, FIN-00014, Helsinki, Finland
}

\begin{abstract}
The occurrence of vascular plants was surveyed on 207 islands (size range $0.01-390.2$ ha, number of plant species 1-449) offshore from the city of Helsinki in the Baltic Sea to examine the conservation value of these islands. We calculated a rarity score for each species (1/number of islands occupied by the species) and a biodiversity score for each island (sum of the rarity scores of each species present on the island). Positive correlations between species number and biodiversity score $\left(\mathrm{r}_{\mathrm{s}}=0.97, \mathrm{p}<0.001\right)$ and between biodiversity score and island area $\left(\mathrm{r}_{\mathrm{s}}=0.87, \mathrm{p}<0.001\right)$ indicated that these parameters are beavily dependent on island size. With the goal of including at least one occurrence (island) of all plant species, an iterative selection algorithrn chose a set of 41 islands whose average size $(29.3 \mathrm{ha})$ was four times the average size of all existing islands ( $7.0 \mathrm{ba}$ ). Strong nestedness ( $\mathrm{N}<54$ ) explains the concentration of plant species diversity on large islands. $\boldsymbol{A} n$ operational strategy for selection of sites for protection is to complement the set produced by a selection algorithm with target species not yet included (e.g., endangered species with several occurrences). Comprebensive mapping and analysis of a taxonomic group will belp integrate conservation biology into land-use planning and increase the quality of the networks of protected areas.
\end{abstract}

Selección de Islas para Conservación en el Archipielago Urbano de Helsinki, Finlandia

Resumen: Muestreamos la presencia de plantas vasculares en 207 islas (rango de tamaño 0.01-390.2 ba, número de plantas 1-149) en las costas de la ciudad de Helsinki, en el mar Báltico para examinar el valor de conservación de estas islas. Calculamos un indice de rareza para cada especie (1/número de islas ocupadas por la especie) y un índice de biodiversidad para cada isla (suma de los índices de rareza de cada especie presente en la isla). Correlaciones positivas entre nímero de especies y el indice de biodiversidad $\left(\mathrm{r}_{\mathrm{s}}=0.97\right.$, $\mathrm{p}<0.001)$ y el indice de biodiversidad y el área de la isla $\left(\mathrm{r}_{\mathrm{s}}=0.87, \mathrm{p}<0.001\right)$ indicaron que estos parámetros som altamente dependientes del tamaño de la isla. Con la meta de incluir al menos una ocurrencia (isla) para todas las especies de plantas, un algoritmo de selección escogió 41 islas, cuyo tamaño promedio (29.3 ha) fue cuatro veces el tamaño promedio de todas las islas $(7.0 \mathrm{ba}$ ). La fuerte anidación $(\mathrm{N}=54)$ explica la concentración de la diversidad de especies de plantas en islas grandes. Una estrategia operacional para la selección de sitios para su protección complementaría el juego de sitios producido por la selección de algoritmo con especies blanco aún no incluídas (e.g., especies amenazadas con varias ocurrencias). El mapeo comprensivo y el análisis de un grupo taxonómico podría ayudar a integrar la biología de la conservación en la planeación de uso del suelo e incrementar la calidad de las redes de áreas protegidas.

Semail pertinanta@metsatabi.inet.fi, jariniemela@belsinki.fi

Paper submitted June 8, 1998; retised manuscript accepted March 10. 1909 


\section{Introduction}

A crucial issue in planning representative networks of protected areas is how to select the sites. Several selection algorithms have been published (e.g., Nicholls \& Margules 1993; Pressey et al. 1993, 1997; Underhill 1994; Williams et al. 1996; Freitag et al. 1997), but usually the selection units have been grid cells of equal size and the algorithms have been mostly applied at national or regional level. Only a few local-level applications have been offered (Game \& Peterken 1984; Rapoport et al. 1986). Furthermore, selection methods have been developed and tested in floristically rich areas with many endemic species, such as southern Africa and Australia (Margules et al. 1988; Rebelo \& Siegfried 1992; Lombard et al. 1997; Pressey et al. 1997).

In the species-poor northern boreal region, on the other hand, there are no globally important hotspots of endemism. For instance, the entire flora of Finland does not include a single endemic vascular plant species. Our focus is on protecting nationally or locally significant biodiversity. To achieve this there is a need to develop methods and tools for local conservation-oriented planning because municipalities, the basic land-use planning units, frequently include biodiversity conservation in their planning principles.

The purpose of our study was to establish which islands of a group of 207 in an archipelago would need to be protected to maintain the diversity of vascular plants. This represents a typical planning situation in which real land units instead of grid cells are used. The selection was based on a comprehensive database of vascular plants.

\section{Methods}

\section{Study Area and Databases}

The archipelago offshore from the city of Helsinki in the eastern Baltic consists of 315 islands (City of Helsinki Urban Facts 1998). The 207 islands included in our study (size range $0.01-390.2$ ha) comprised practically all the "real" islands inside Helsinki city limits; small rocks pro truding from the sea were excluded because they lack vascular plants. Most of the islands studied are uninhab ited, but several large ones close to the mainland have permanent human settlement. The occurrence (presence-absence) of vascular plants on the islands was mapped by the author A.K. and his collaborators between 1990 and 1995.

Islands in the Baltic have risen from the sea since the last glaciation. Land uplift of approximately $2.5 \mathrm{~mm} /$ year makes new islands appear continuously and existing ones expand. The islands studied consist of Precambrian bedrock with a thin layer of topsoil. The natural vegetation on the larger islands typically consists of low Scots pine (Pinus sylvestris) forest with heather (Calluna wul- garis), bilberry (Vaccinium myrtillus), and cowberry (Vaccinium vitis-idaea) as dominant species in the field layer. In protected bays, common alder (Alnus glutinosa) groves are found with more luxuriant vegetation. Small islands lack forests and are characterized by stony shore-meadows and patches of meadow vegetation in depressions and rock fissures. Bare rock surfaces are common on exposed shores on both large and small islands. The ecological features of the study area are comparable to those of other archipelagos in the Baltic (Ås et al. 1992).

\section{Calculations}

We calculated a rarity score for each plant species: $1 / c_{i}$, $\left\{c_{i}<>0,1 \leq i \geq n\right\}$, where $c_{i}$ is the number of islands occupied by species $i$. The biodiversity score of an island was the sum of the rarity scores of all species occurring on it.

Several algorithms have been developed for reserve selection (Saetersdal et al. 1993; Lombard et al. 1995; Csuti et al. 1997; Pressey et al. 1997). Common to all these algorithms is that they start from an empty selection, adding new areas in the most effective way until the predetermined goal is reached. For instance, the goal may be to include all species at least once.

We used an inverted method to select a near-minimum set of islands that includes all vascular plant species present in the archipelago. The algorithm "most common" (MC) starts with all the islands included and eliminates one island in every cycle until the selected stop level has been reached. Initially, MC calculates the number of occurrences-the number of islands on which the species occurs-for every species (step 1) and identifies the rarest species on each island (step 2; Fig. 1). The algorithm then ranks the islands according to the number of occurrence of the rarest species. Other species on each island are ignored (step 3). At this stage, each island is represented by only one species, the rarest. Thereafter, MC finds the island with the rarest species with the highest number of occurrences (step 4 ). The rarest species on each island is the species with fewest occurrences. The MC then starts eliminating islands where the number of occurrences of the rarest species is highest (condition 1). This island may be interpreted as least valuable. The eliminating order follows the number of occurrences of species as the number of islands included gradually decreases (step 5). The MC recalculates the frequencies of all species on the remaining islands and again identifies the rarest species on each island.

Cyclical elimination continues until the rarest species on each of the remaining islands occurs on only one is land. This means every island in the set has at least one unique species (condition 1). Setting the stop level to zero produces a numerical order of all islands. This is an 


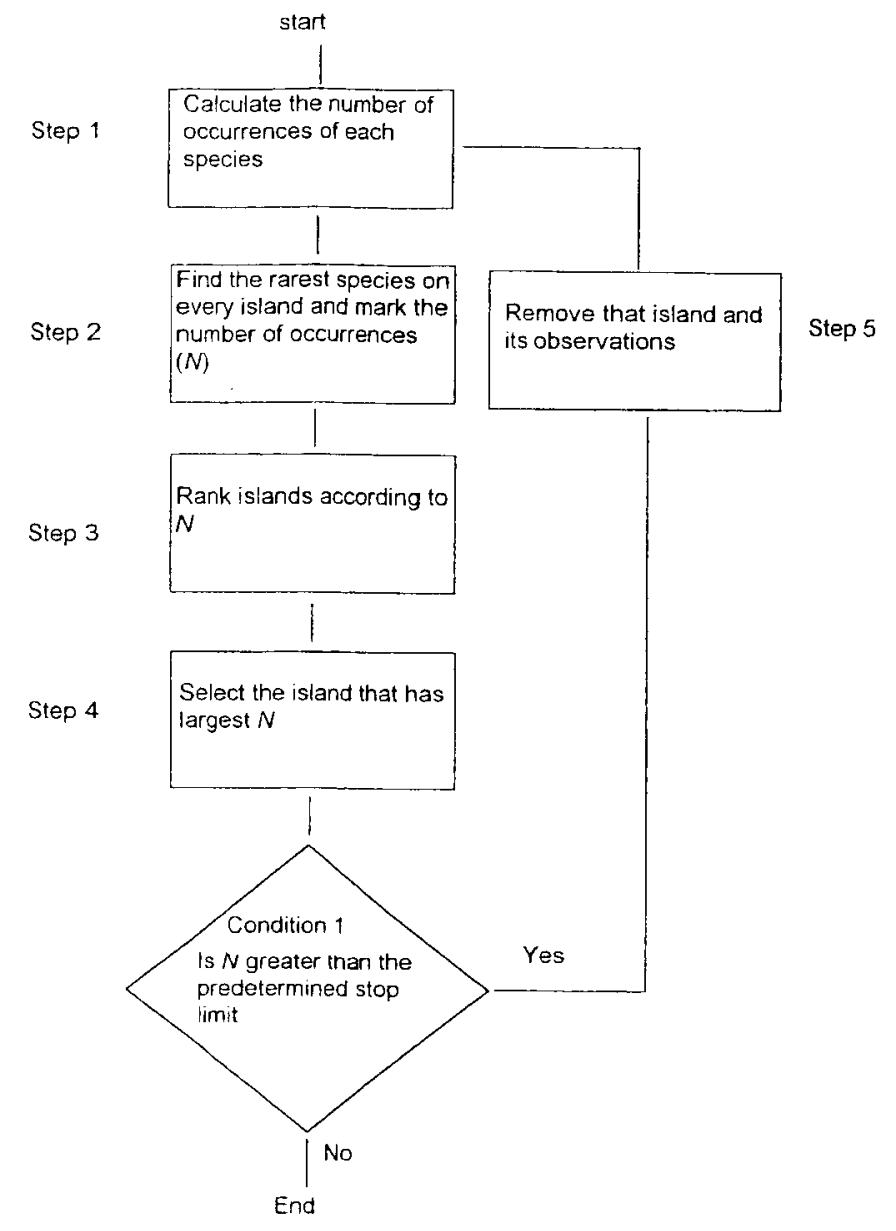

Figure 1. Flow diagram of the algoritbm "most common" for reserve selection.

advantage of MC that makes it possible to compare islands according to the relative rarity of their species.

The stop level may be set to any nonnegative value. For instance, stop level one produces a set of islands that contains all species at least once. If species occur on fewer than or on a number of islands equal to the selected stop level, those islands will be automatically included in the near-minimum set. The MC also gives the numerical rank of those islands not included in the nearminimum set (Fig. 1). If the rarest species have the same number of occurrences on several islands, the island with the lowest biodiversity score will be chosen (step 4). Other elimination rules could also be applied, such as the largest island (lower cost of establishing protection) or most remote island (maximization of continuous area).

To investigate nestedness among species assemblages we used the index $N$ (Patterson \& Atmar 1986), which measures how much the observed presence-absence matrix differs from perfect nestedness $(N=0)$. The maximum value of $N$ (i.e., minimum nestedness) depends on the size of the matrix and the number of species present.
For the analysis, we divided the islands into four size classes: 0.01-0.09 ha (28 islands), 0.1-0.99 ha ( 83 islands), $1.0-9.9$ ha ( 76 islands), and $>10.0$ ha (20 islands). The analyses were also made without size classes.

\section{Results}

\section{Occurrence and Nestedness of Species}

We made 22,364 observations of 686 vascular plant species (hybrids were excluded) on the 207 islands (1-449 species/island). Most of the species were rare in our clata; about 400 species occurred on $<20$ islands $(<10 \%$ of islands), and the number of species occurring only on one island was 108. Rare species were clearly concentrated on a small group of islands: 11 islands hosted more than 100 rare species each. Common species were few in number, with only 20 species occurring on more than 155 islands (Fig. 2).

The island-specific biodiversity score varied from 0.1 to 40.3. Fifty islands had a biodiversity score of $<1.0$ (Table 1). The value of the biodiversity score depended both on the rarity of species on an island and on the island's species richness. Because one unique species has the same weight as 100 relatively common species (occurring on $>100$ islands), score values increased rapidly with the presence of rare species.

Occurrence of the plant species showed strong nestedness $(N=54)$. The value of the index $N$ would be 640 if the plant species were randomly distributed among the islands, and maximum $N=1056$. The species assemblages of the small island size classes were included within the large island size classes, and rare species occurred almost exclusively on islands falling into the largest size class. Without size classes, nestedness was weaker $(N=46,975)$, and maximum $N=119,640$. This was due to a great number of small islands of almost the same size and only slight variation of species composition.

\section{Selection of Minimum Sets of Islands}

\section{"MOST COMMON" ALGORITHM}

Forty-one islands were needed in a minimum set of islands that included all the plant species at least once (Table 2). The set represents $20 \%$ of the 207 islands studied but as much as $83 \%(1200.4$ ha) of the total island area. The average size of an island included in the minimum set ( 29.3 ha) was over four times the average island size among all 207 ( $7.0 \mathrm{ha}$ ).

Because the preservation of a single occurrence of a species does not guarantee its long-term survival, minimum sets of islands were established for 1-178 occurrences (number of islands occupied) for each species. The total island area included in the minimum set in- 


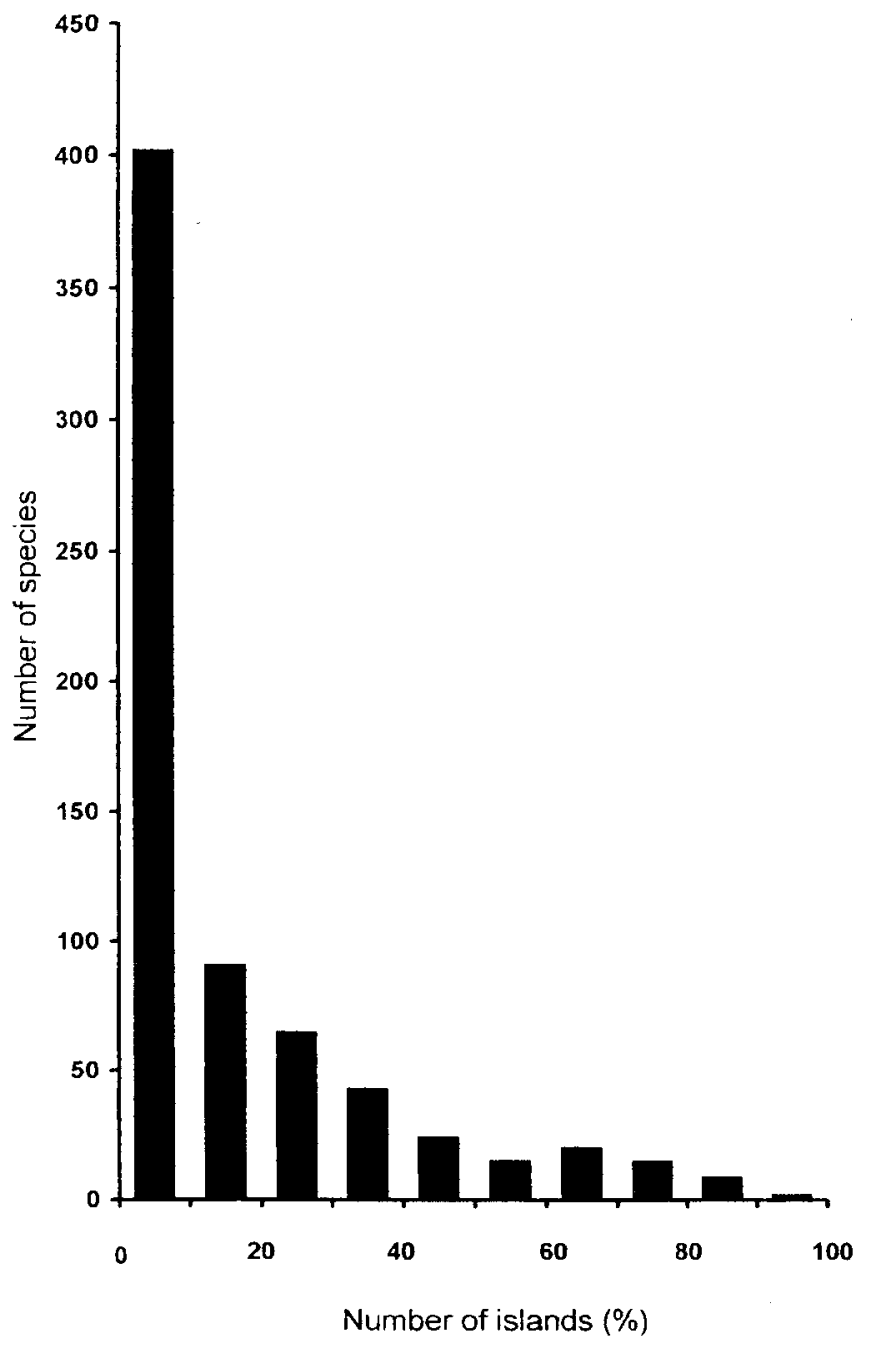

Figure 2. Occurrence of vascular plant species on the islands studied. Most species are rare: over 400 species grow on only $10 \%$ or less of all islands.

Table 1. Distribution of land area, number of species, and sums of biodiversity scores among size classes of islands offshore from Helsinki.

\begin{tabular}{lcccc}
\hline Size class & $\begin{array}{c}\text { Number } \\
\text { of islands }\end{array}$ & $\begin{array}{c}\text { Total area } \\
\text { (ba) }\end{array}$ & $\begin{array}{c}\text { Number } \\
\text { of species }\end{array}$ & $\begin{array}{c}\text { Sum of } \\
\text { biodiversity } \\
\text { scores }\end{array}$ \\
\hline $0.01-0.09$ & 28 & 1.8 & 162 & 8.7 \\
$0.1-0.99$ & 83 & 38.6 & 323 & 67.5 \\
$1.0-9.9$ & 76 & 239.4 & 555 & 259.6 \\
$>10.0$ & 20 & 1172.3 & 648 & 350.2 \\
Total & 207 & 1452.2 & 686 & 686.0 \\
\hline
\end{tabular}

creases rapidly to almost $100 \%$ as the number of predetermined species occurrences increases (Fig. 3). For instance, a minimum set of islands consisting of more than 20 occupied istands for each species included practically the entire island area but only approximately 150
Table 2. The 41 islands off Helsinki included in the minimum set selected by the "most common" algorithm for reserve selection and six other islands ${ }^{4}$ selected by target species (threatened species).

\begin{tabular}{|c|c|c|c|c|}
\hline Island & $\begin{array}{c}\text { Island } \\
\text { area } \\
\text { (ba) }\end{array}$ & $\begin{array}{l}\text { Number } \\
\text { of plant } \\
\text { species }\end{array}$ & $\begin{array}{c}\text { Biodiversity } \\
\text { score }\end{array}$ & $\begin{array}{c}\text { Land-use } \\
\text { type }\end{array}$ \\
\hline Pieni Leikosaari* & 1.16 & 97 & 1.2 & pri \\
\hline Kuminapaasi & 0.52 & 59 & 1.5 & pub \\
\hline Matalahara & 2.52 & 84 & 1.8 & res \\
\hline Koirasaari* $^{*}$ & 3.24 & 136 & 2.4 & pub \\
\hline Päntäri & 3.60 & 93 & 2.4 & pub \\
\hline Kalkkipaasi & 0.29 & 78 & 2.4 & pub \\
\hline Harmaja* & 1.84 & 115 & 1.8 & mil \\
\hline Korkeakupu & 0.53 & 54 & 2.8 & pub \\
\hline \multicolumn{5}{|l|}{ Pikku } \\
\hline Lehdessaari & 1.60 & 141 & 3.3 & pri \\
\hline Malkasaari & 3.44 & 141 & 3.5 & pub \\
\hline Jänissaari* & 3.90 & 160 & 3.6 & $\mathrm{mil}$ \\
\hline Tïrasaari & 3.14 & 167 & 3.9 & pri \\
\hline Luoto (Klippan) & 1.80 & 139 & 4.0 & pub \\
\hline Pikku Kuivasaari* & 2.08 & 185 & 4.0 & $\mathrm{mil}$ \\
\hline \multicolumn{5}{|l|}{ Vallisaaren } \\
\hline Pukkisaari & 4.76 & 160 & 4.5 & mil \\
\hline Pihlajaluoto & 3.28 & 185 & 4.7 & pub \\
\hline Uunisaaret & 2.20 & 157 & 4.7 & pub \\
\hline Iso Leikosaari & 5.26 & 192 & 4.8 & pri \\
\hline Pikku-Musta & 4.00 & 178 & 5.7 & pub (sf) \\
\hline Kotiluoto & 3.36 & 185 & 6.4 & pub \\
\hline Rysäkari & 10.04 & 225 & 7.0 & mil \\
\hline Hylkysaari & 4.00 & 223 & 7.3 & pub \\
\hline Kalkkisaari & 3.33 & 181 & 7.3 & pri \\
\hline Länsi-Musta & 8.50 & 240 & 8.7 & pub \\
\hline Kuivasaari & 11.33 & 244 & 8.8 & mil \\
\hline Reposaari & 2.10 & 206 & 9.0 & pri \\
\hline \multicolumn{5}{|l|}{ Itäinen } \\
\hline Pihlajasaari & 6.84 & 254 & 9.1 & pub \\
\hline Itä-Villinki & 33.30 & 276 & 9.3 & mil \\
\hline \multicolumn{5}{|l|}{ Läntinen } \\
\hline Pihlajasaari & 19.00 & 267 & 10.3 & pub \\
\hline Melkki & 40.50 & 298 & 10.8 & mil \\
\hline Lammassaari & 8.70 & 248 & 11.0 & pub \\
\hline Pikku Niinisaari & 31.88 & 257 & 11.2 & pri + pub \\
\hline Mustikkamaa* & 37.50 & 304 & 12.8 & pub \\
\hline Harakka & 8.80 & 307 & 14.2 & res \\
\hline Vasikkasaari & 17.94 & 295 & 14.7 & pri \\
\hline Korkeasaari & 25.30 & 265 & 14.8 & pub \\
\hline Kuninkaansaari & 37.20 & 322 & 14.9 & $\mathrm{mil}$ \\
\hline Kustaanmeikka & 33.50 & 275 & 15.0 & pub (sf) \\
\hline Palosaari & 2.00 & 195 & 15.3 & pri \\
\hline Seurasaari & 40.60 & 310 & 18.3 & pub \\
\hline Susisaari & 33.50 & 310 & 19.4 & pub (sf) \\
\hline Villinki & 134.50 & 375 & 21.8 & pri + pub \\
\hline Isosaari & 73.35 & 355 & 22.0 & mil \\
\hline Iso Mustasaari & 24.40 & 270 & 23.5 & pub (sf) \\
\hline Vartiosaari & 89.00 & 352 & 31.7 & pri + pub \\
\hline Santahamina & 390.20 & 449 & 38.9 & mil \\
\hline Vallisaari & 76.70 & 415 & 40.2 & mil \\
\hline
\end{tabular}

"These six other islands are marked with an asterisk.

${ }^{b}$ Land-use type: pub, public area: res, nature reserte; pri. pritate area; sf, Suomenlinna sea fortress; mil, military or coast guard area

islands. This implies that the islands not included in this minimum set were small and had few plant species.

On the other hand, the number of occurrences of many plant species remains below the selected number 


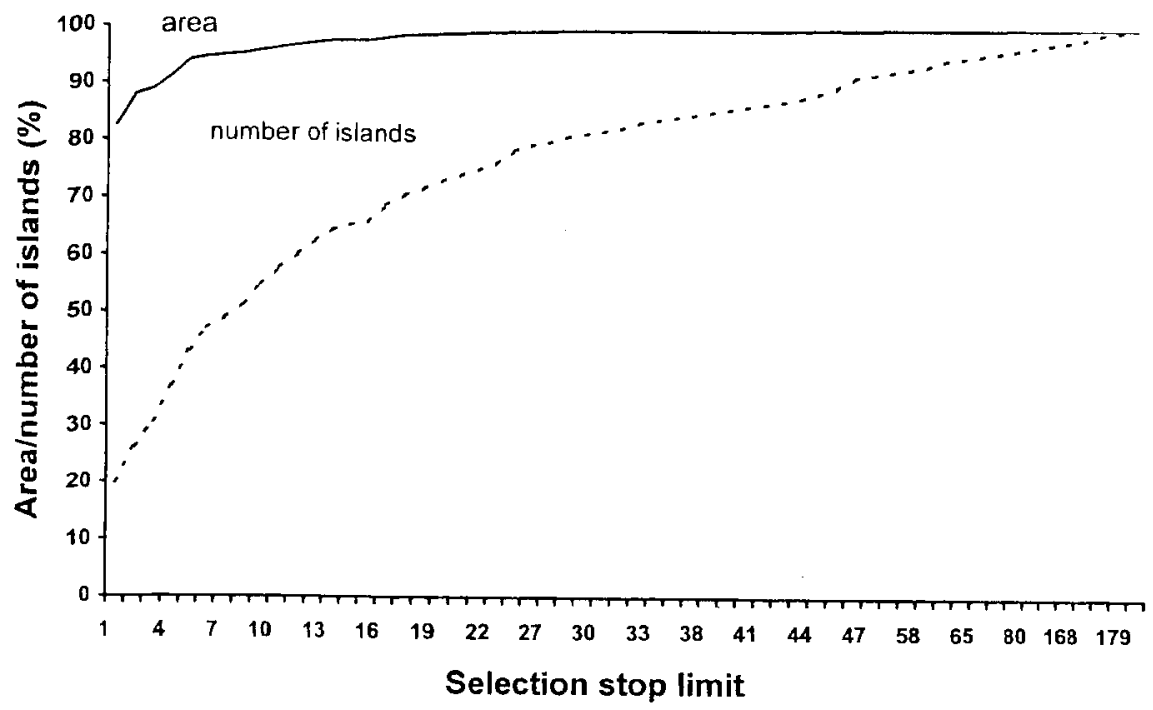

Figure 3. Cumulative increase in area and number of islands at selection stop limits from 1 to 178 (minimum sets with 1-178 occurrences). of occupied islands because they do not occur on so many islands. Consequently, the increase in the number of islands selected does not have a positive effect on the future persistence of very rare species in that a species occurring on a certain number of islands will not occur on more islands regardless of the number of islands selected for protection.

\section{SELECTION BY TARGET SPECIES}

To examine the usefulness of the most common algorithm (MC) we compared sets of islands selected by it and sets selected by other methods. A simple method of selecting sites for protection is to use target species. We made the selection using two kinds of pre-defined target species: (1) unique species (108 species with only one occurrence) and (2) nationally or provincially threatened species (1/1 species; Rassi et al. 1992).

Unique species were found on 37 islands. The five most unique species-rich islands had nearly half (53) of the 108 species, and they were also among the most species-rich islands. Because islands with a unique species were automatically included in the minimum set of 41 , only four of the minimum set did not harbor unique species. Thus, selection using MC with stop level 1 and selecting the islands harboring unique species gave nearly the same set of islands.

Selecting islands based on the occurrence of threatened species produced a somewhat different set. The 14 threatened species occurred on 24 islands, 18 of which were the same as in the minimum set produced by MC. Threatened species were found mostly on large, speciesrich islands. The combination of the two target species groups as a selection criterion produced a set of 43 islands with 6 different islands than were in the minimum set produced by MC. (Table 2 ).

\section{BIODIVERSITY SCORE, ISLAND SIZE, OR SPECIES NUMBER}

The sum of the biodiversity scores of the minimum set of 41 islands selected using MC was $466.2,68 \%$ of the value of the whole archipelago. Comparing the MC-produced set of 41 with a set of the same number of islands with the highest biodiversity score revealed that 32 islands are the same in each group. Thus, selection using the biodiversity score produces a set fairly similar to that using the algorithm.

Other criteria for selection might include island size and species richness. A comparison between the set of 41 islands produced by $\mathrm{MC}$ and the 41 largest islands revealed that 25 islands are in both groups. A similar comparison between the MC set and the 41 most speciesrich islands revealed that 31 are the same in each set. In both comparisons, practically all of the 20 highestranked islands are also included in the minimum set produced by MC.

The observation that island size, species richness, and biodiversity score produced a set of islands similar to that produced by MC indicates the high correlation between these variables. Species number and island size correlated positively $\left(r_{s}=0.88, n=207, p<0.001\right)$, as did island size and biodiversity score $\left(r_{s}=0.87, n=\right.$ $207, p<0.001)$. Furthermore, there was a positive correlation between species number and biodiversity score $\left(r_{s}=0.97, n=207, p<0.001\right)$. These correlations indicate that the conservation value of an island increases with its size.

\section{Discussion}

\section{Ecological Features Important for Conservation Planning}

Our study demonstrates that biodiversity score, island size, and species richness reflect the conservation value 
of the islands studied fairly well. But these parameters do not provide information about species composition and are therefore not useful criteria for conservation evaluation by themselves. The use of species identities in conservation planning is thus preferable.

Furthermore, the strong nestedness among vascular plants in the Helsinki archipelago implies that species-rich islands also harbor the rarer species. Nestedness among species assemblages is a common feature on islands (Patterson 1987, 1990; Blake 1991; Cutler 1991, 1994; Simberloff \& Martin 1991; Wright \& Reeves 1992; Atmar \& Patterson 1993; Cook 1995; Kadmon 1995), but its causes are often unclear (Yiming et al. 1998). In the Helsinki archipelago, nestedness of species is to a large extent explained by the geological history of the islands. As island size increases constantly due to land uplift, pioneer communities invade the islands as soon as suitable habitat appears, and the same communities are present along the shores of the larger islands. Large islands also contain species that occur in habitats that do not exist on smaller islands. Colonization from the mainland or other, larger islands could therefore be the main factor that has generated this nestedness (Patterson 1990; Cook \& Quinn 1995)

\section{Strategy for Conservation Selection}

The "most common" algorithm used here was tested with the Finnish Bird Atlas data $(250,000$ observations, 3,800 grid cells of $10 \times 10 \mathrm{~km}$ ). The algorithm found about the same number of grid cells as the simple greedy algorithm 1 (type 1) presented by Csuti et al. (1997), but the set was different (Tanskanen 1996a, 1996b). Using plant data from the Helsinki archipelago, the progressive rarity algorithm 7 (Csuti et al. 1997) produced a set of exactly the same number of islands as did MC (41 islands), only one island being different. The sea-kale (Crambe maritima) occurred only on these two islands; consequently, one of them had to be included in the set.

The minimum set of 41 islands that included all the species at least once serves as a rough guide to where

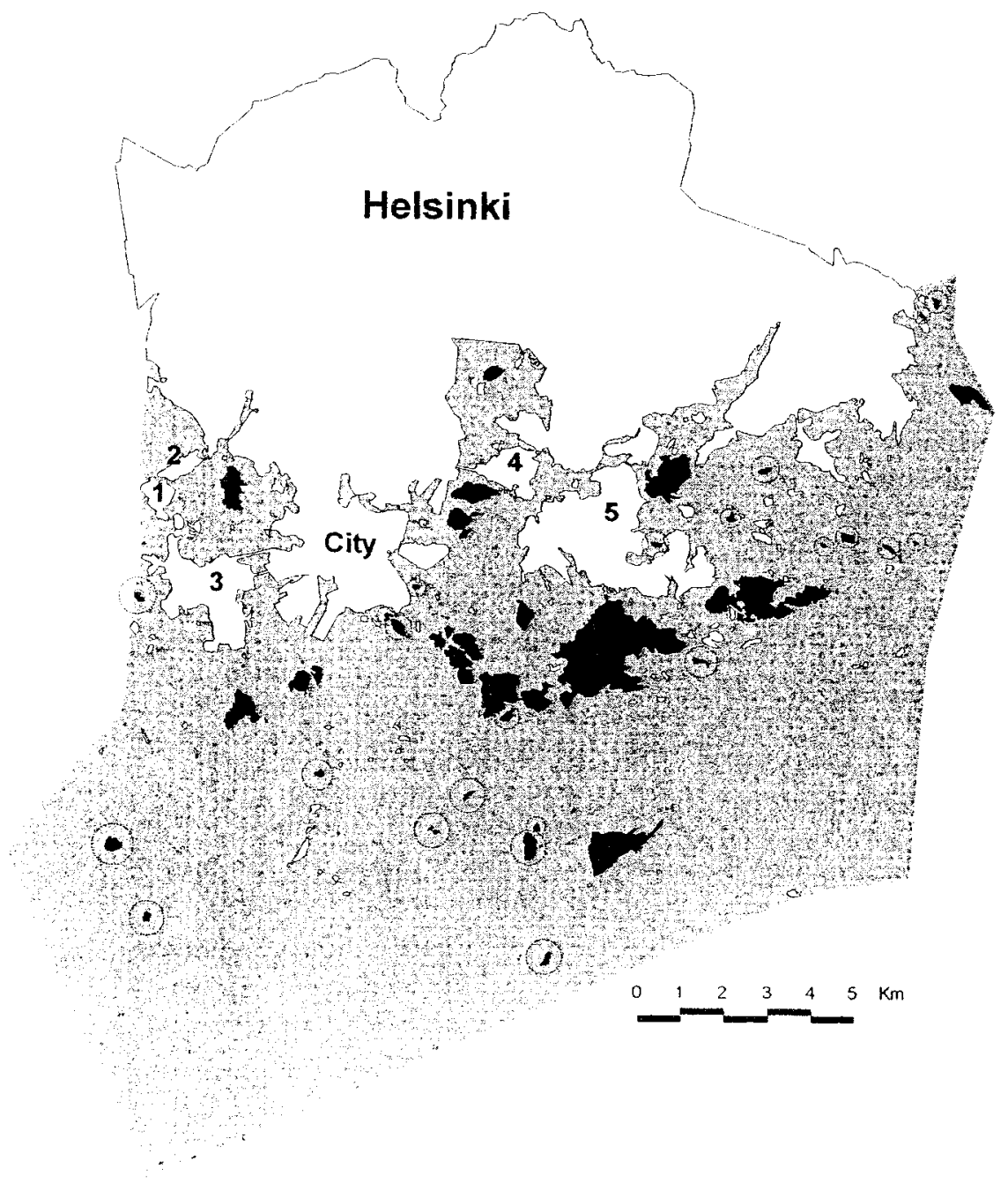

Figure 4. The group of islands se lected for conservation (in black) includes the 41 islands of the minimum set and 6 other islands with threatened species. The numbered islands $(1-5)$ with dense urban settlement were not included in the study area. 
the essential plant diversity exists in the Helsinki archipelago. The selection method needs several refinements, however, to produce results that can be applied in conservation planning. The first consideration is the need for filtering of species. For example, the occurrence of peanut (Aracbis bypogaea) is clearly irrelevant for conservation purposes because it is an accidental introduction and has no viable populations on Baltic islands. Peanut and similar species should be filtered out before the analysis.

Another essential refinement is the inclusion of desirable target species. Because the minimum set may include only one occurrence per species, it does not necessarily include all the islands on which target species (e.g., threatened species) occur. A solution may be a post-selection of the islands harboring target species but not included in the minimum set. $A$ procedure for the selection of islands or other sites for conservation could thus proceed as follows. First, irrelevant species are removed from the database. Second, the selection algorithm selects a set of islands with the required number of occurrences per species. Third, occurrences of target species are ensured by post-selection.

Following this procedure, we selected a network of 41 islands produced by MC on which each species occurred at least once. Thereafter, an additional six islands harboring endangered species not selected by the algorithm were included in the proposed network of protected islands (Fig. 4). Several of the islands found by the algorithm are protected for reasons other than their ecological value (e.g., the World Heritage site of Suomenlinna Sea Fortress). Species found on these already protected islands could be used as a starting point in seeking islands that add new species to the combination. This procedure follows a pragmatic selection strategy, combining reserve selection algorithms with other reserve-design criteria (Bedward et al. 1992).

In an archipelago off a large city with heavy recre ational use such as Helsinki, a network of protection that covers one-fifth of the islands, and as much as four-fifths of the total area, would hardly be realistic. For maintaining biodiversity, however, there is no need to protect entire islands or to exclude other types of land use from the islands selected, if essential habitat patches are preserved. These patches may cover only a small fraction of the island area. For example, a habitat-based plant mapping was done on the island of Isosaari (73 ha). The isand was included in the minimum network (355 speies, 7 of them unique and 3 threatened), but the habitat ttches supporting these species represented only about i of the total area of the island. If a comprehensive habmap is not available, the list of habitat specialists with ow size range could be used for the identification of nost important habitats for protection.

$r$ study emphasises the need for comprehensive, fuality ecological databases for conservation evalu- ation. Unfortunately, these are relatively rare, especially for larger areas. Furthermore, as mentioned above, there are strong arguments that each habitat patch should also be analyzed separately (Deshaye and Morisset 1988; Worthen 1996). Experienced professionals are needed to carry out the fieldwork, which may take several field seasons. This requires a substantial investment in research work, but the total cost of comprehensive mapping of a taxonomic group (e.g., vascular plants) in a city like Helsinki (land area $187 \mathrm{~km}^{2}$ ) is modest compared with investments needed in urban infrastructure planning in general. Consequently, the fundamental issue is recognition of the importance of the incorporation of conservation biology into the planning process and the acceptance of the associated costs.

\section{Acknowledgments}

This study was financially supported by the City of Helsinki Environment Centre and the Finnish Biodiversity Research Programme (grant 39715). We are thankful to L. Helynranta for help in the field and to J. Kotze for constructive comments on the manuscript.

\section{Literature Cited}

As, $S_{,}, J$. Bengtsson, and T. Ebenhard. 1992. Archipelagoes and theories of insularity. Pages 201-251 in L. Hansson, editor. Ecological principles of nature conservation. Elsevier Applied Science, London.

Atmar, W., and B. D. Patterson. 1993. The measure of order and disorder in the distribution of species in fragmented habitat. Oecologia 96:373-382.

Bedward, M., R. I. Pressey, and D. A. Keith. 1992. A new approach for selecting fully representative reserve networks: addressing efficiency, reserve design and land suitability with an iterative analysis. Biological Conservation 62:115-125.

Blake, J. G. 1991. Nested subsets and the distribution of birds on isolated woodlots. Conservation Biology 5:58-66

City of Helsinki Urban Facts. 1998. Environmental statistics of Helsinki. City of Helsinki, Helsinki

Cook, R. R. 1995. The relationship between nested subsets, habitat subdivision, and species diversity. Oecologia 101:204-210

Cook, R. R., and J. F. Quinn. 1995. The influence of colonisation in nested species subsets. Oecologia 102:413 424

Csuti, B., S. Polasky, P. H. Williams, R. L. Pressey, J. D. Camm, M. Ker shaw, A. R. Kiester, B. Downs, R. Hamilton, M. Huso, and K Sahr 1997. A comparison of reserve selection algorithms using data on rerrestrial vertcbrates in Oregon. Biological Conservation 80:83-97.

Cutler, A. 1991. Nested faunas and extinction in fragmented habitats Conservation Biology 5:496-505.

Cutler, A. 199\%. Nested biotas and biological conservation: metrics, mechanisms, and meaning of nestedness Landscape and Lrban Planning 28:73-82.

Deshaye, J., and P. Morisset. 1988. Floristic richness, area, and habitat diversity in a hemiarctic archipelago. Journal of Biogeography 15: $747-757$.

Freitag, S., A. S. van Jaarsveld, and H. C. Biggs. 1997. Ranking priority biodiversity areas: an iterative conservation value-based approach Biological Conservation 82:263-272.

Game, M., and G. F. Peterken. 1984. Nature reserve selection strategies 
in the woodlands of central Lincolnshire, England. Biological Conservation 29:157-181

Kadmon, R. 1995. Nested species subsets and geographic isolation: a case study. Ecology $76: 458-465$.

Lombard, A. T, A. O. Nicholls, and P. V. August. 1995. Where should nature reserves be located in South Africa? A snake's perspective. Conservation Biology 9:363-372.

Lombard, A. T., R. M. Cowling, R. L. Pressey, and P. J. Mustart. 1997. Reserve selection in a species-rich and fragmented landscape on the Agulhas Plain, South Africa. Conservation Biology 11:1101-1116.

Margules, C. R., A. O. Nicholls, and R. L. Pressey. 1988. Selecting networks of reserves to maximise biological diversity. Biological Conservation 43:663-676

Nicholls, A. O., and C. R. Margules. 1993. An upgraded reserve selection algorithm. Biological Conservation 64:165-169.

patterson, B. D. 1987. The principle of nested subsets and its implica tions for biological conservation. Conservation Biology 1:323-334.

Patterson, B. D. 1990. On the temporal development of nested subset patterns of species composition. Oikos 59:330-342.

Patterson, B. D., and W. Atmar. 1986. Nested subsets and the structure of insular mammalian faunas and archipelagos. Biological Journal of the Linnean Society 28:65-82.

Pressey, R. L., C. J. Humphries, C. R. Margules, R. I. Vane-Wright, and P. H. Williams. 1993. Reyond opportunism: key principles for systematic reserve selection. Trends in Ecology and Evolution 8:124-128.

Pressey, R. L., H. P. Possingham, and J. R. Day. 1997. Effectiveness of alternative heuristic algorithms for identifying indicative minimum requirements for conservation reserves. Biological Conservation 80:207-219.

Rapoport, E. HI., G. Borioli, J. A. Monjeau, J. E. Puntieri, and R. D. Oviedo 1986. The design of nature reserves: a simulation trial for assessing specific conservation value. Biological Conservation 37:269-290.
Rassi, P., H. Kaipiainen, I. Mannerkoski, and G. Stăhls, editors. 1992 Uhanalaisten eläinten ja kasvien seurantatoimikunnan mietintö. [Report on the monitoring of threatened animals and plants in Finland.] Komiteamietintö 1991:30. Ympäristöministeriö, Helsinki.

Rebelo, A. G., and W. R. Siegfried. 1992. Where should nature reserves be located in the Cape Floristic Region, South Africa? Models for the spatial configuration of a reserve network aimed at maximizing the protection of floral diversity. Conservation Biology 6:243-252.

Saetersdal, M., J. M. Line, and H. J. B. Birks. 1993. How to maximize biological diversity in nature reserve selection: vascular plants and breeding birds in deciduous woodlands, Western Norway. Biological Conservation 66:131-138.

Simberloff, D., and $\mathbf{J}$-L. Martin. 1991. Nestedness of insular avifaunas: simple summary statistics masking complex species patterns. Ornis Fennica 68:178-192

Tanskanen, A. $1996 a$. Näkökulmia lintuatlakseen 1. Mistä bongaan Suomen pesimälinnut? Linnut 5:12-15.

Tanskanen, A. 1996b. Näkökulmia lintuatlakseen 2. Säästäkää edes nämä! Linnut 6:31-33.

Underhill, L. G. 1994. Optimal and suboptimal reserve selection algorithms. Biological Conservation 70:85-87.

Williams, P., D. Gibbons, C. Margules, A. Rebelo, C. Humphries, and R. Pressey. 1996. A comparison of richness hotspots, rarity hotspots, and complementary areas for conserving diversity of British birds. Conservation Biology 10:155-174.

Worthen, W. B. 1996. Community composition and nested-subset anal yses: basic descriptors for community ecology. Oikos 76:417-426.

Wright, D. H., and J. H. Reeves. 1992. On the meaning and measurement of nestedness of species assemblages. Oecologia 92:416-428.

Yiming, L., J. Niemelä, and L. Dianmo. 1998. Nested distribution of amphibians in Zhoushan archipelago, China: can selective extinction cause nested subsets of species? Oecologia 113:557-564. 